\title{
Ucieczka w postkolonialność. Pułapki wschodnioeuropejskiego dyskursu teorii postkolonialnej
}

\section{Abstract \\ Escape to Postcolonialism. Traps of the East European Discourse of Postcolonial Theory}

The paper discusses the circulation of the concept of postcoloniality from Western Academia to Eastern European context of research. On the one hand, the proliferation of meanings of postcoloniality results from the heterogeneity of the postcolonial theory that combines various components of postmodern, feminist and emancipatory discourses. On the other hand, the notions of "postcoloniality" and "postcolonial society" become vaguely comprehensive and too easily identified with post-communism or post-socialism. At the turn of the century many researchers decided to incorporate the concept of a historical European domination over the Orient and people from the Middle East to analyse the relics of communist regimes in Eastern Europe: a colonialized man has been transformed into a homo sovieticus. The paper focuses on the concepts borrowed from the postcolonial theory which used in the Eastern European context might change into an ideological voice trapped in the specific discourse of modernization and otherness.

Keywords: postcolonial theory, Eastern Europe, modernization, post-communism, post-socialism

Modne nurty refleksji i nośne kategorie w szczególny sposób są wystawione na przechwycenie, modyfikowanie, a w konsekwencji na rozmycie pierwotnej specyficzności. Takim nurtem wydaje się dziś w Europie Wschodniej postkolonializm, kategorią - postkolonialność, a narzędziem przeobrażeń - różnego typu dyskursy modernizacyjne (także w wariancie konserwatywnym). Celem niniejszego ar- 
tykułu jest problematyzacja zarówno współczesnego rozplenienia znaczeń i zastosowań kategorii postkolonialności, jak i ich wartościującego oraz esencjalizującego rzeczywistość społeczną charakteru, który w kontekście kryzysu polityk równościowych i tolerancji pozytywnej może niepokojąco współbrzmieć z dyskursami populistycznymi oraz skrywać pod postacią postulatów godnościowych treści etnocentryczne i tradycjonalistyczne (zob. Bill 2014).

Wychodząc od rozumienia postkolonialności jako materialno-symbolicznej kondycji społeczeństw zdekolonizowanych w wymiarze formalno-prawnym, ale wciąż uzależnionych od metropolii (zwłaszcza w wymiarze kulturowym), teoria postkolonialna absorbowała, z jednej strony, dyskursy postmodernistyczne, a z drugiej rozmaite lokalne konteksty - tworząc montaż wiedzy, krytyki i roszczeń spięty umowną klamrą. W rezultacie proliferacji sensów kategoria postkolonialności ulega wtórnej ideologizacji. W szczególny sposób wchłonięcie krytycznego potencjału postkolonializmu przez krytykowane dyskursy polityczne dotyczy wschodnioeuropejskiego wariantu teorii, sprzęgniętego z kategoriami postsocjalizmu i postkomunizmu. Ujęcie refleksji nad tym obszarem Europy $\mathrm{w}$ ramy teorii postkolonialnej nie zawsze prowadzi do poznawczego zysku. Niekiedy wiąże się z subtelną reifikacją podziałów na zmodernizowany Zachód i zapóźniony Wschód, a nawet $\mathrm{z}$ odpryskami kulturowego neokolonializmu - poprzez bezkrytyczne zapożyczenia z zachodnich teorii.

Warto za Dorotą Kołodziejczyk (2010: 22) powtórzyć, że być może „postkolonializm nie jest konieczny do definiowania pozycji i roli poszczególnych krajów Europy Środkowej i Wschodniej w perspektywie historycznej i współczesnej względem dawnych imperiów czy Europy Zachodniej”. Proponuję uzupełnić tę tezę pytaniem o paradoksalną produktywność wschodnioeuropejskiego dyskursu teorii postkolonialnej w obszarze wytwarzania i uzasadniania określonych scenariuszy modernizacji.

\section{Przezroczystość pojęcia}

Teoria postkolonialna, od początków swojej instytucjonalizacji na przełomie lat 70. i 80. XX wieku, stanowi nurt heterogeniczny, a wspólnym mianownikiem różnych jego strumieni jest zaangażowana krytyka kondycji społecznej i kulturowej świata po politycznej dekolonizacji.

Najwięcej rozbieżności między badaczami rodzi jednak sama kategoria postkolonialności. Z jednej strony jej geneza odsyła do perspektywy politologicznej i historycznej - początkowo kategoria ta miała wymiar przede wszystkim geopolityczny i temporalny, odnosiła się do okresu po dekolonizacji państw Afryki i Azji. Z drugiej teoria postkolonialna szybko zaczęła inkorporować elementy dyskursów postmodernistycznych, feministycznych i emancypacyjnych. W konsekwencji sens kategorii „postkolonizowanych” rozszerzył się na konteksty kla- 
sowe, płciowe czy seksualne. Jak zauważa Ania Loomba (2011: 23), „przedrostek «post» (...) sugeruje następstwo w dwóch znaczeniach - czasowym, jako przychodzący po kolonializmie, oraz ideologicznym, jako zajmujący jego miejsce”. Ten drugi sens budzi największe kontrowersje, ponieważ jeżeli zakładamy, że ideologia kolonialnych podziałów jest kontynuowana, to czy w ogóle można mówić o jakimś postetapie? A może przeciwnie - należy właśnie odróżniać kolonializm par excellence od jego ideologicznej spuścizny? Wreszcie w jaki sposób ustalana jest cezura między kolonializmem par excellence a jego post- lub neonastępstwami? Czy miarą postkolonialnego czasu nie jest kalendarz Zachodu (McClintock 1992: 86-87), którego ekskluzywną racjonalność postkolonializm chciałby zakwestionować i zdekonstruować (Gandhi 2008; Hall 1996)?

Pojęcie postkolonialności splata się z krytyką procesów neokolonizacyjnych, westernizacji i modernizacji imitującej zachodnie rozwiązania, a także z krytyką metody historycznej analizy czasu kolonii i jej pokłosia (Ascione 2016, w kontekście wschodnioeuropejskim zob. także Domańska 2016). Rewersem tej krytyki jest dążenie nie tylko do wyrugowania nierówności wynikających z dyskursów różnicy kulturowej, ale także emancypacja $z$ hierarchii determinowanych przez konstrukty klasy, płci czy seksualności, a więc te, które kwestionuje zachodnia teoria podmiotu, a które mogą być ważnym (choć problematycznym) punktem odniesienia dla tożsamości zbiorowych społeczeństw skolonizowanych (Domańska 2008: 167-168). Chronologiczne i diachroniczne logiki lektury postkolonialności splatają się z sobą i wzajemnie dopełniają - tworząc w pewnej mierze wewnętrznie sprzeczny twór, oparty na fantazmatycznym stosunku zarówno do wyobrażonego Wschodu, jak i do wyobrażonego Zachodu. Idea postępu i modernizacji społecznej oraz prymatu tradycji jednocześnie odpychają i przyciągają się (w kontekście polskim zob. Zarycki 2014). Innymi słowy, bez dorobku zachodniego liberalizmu nie byłoby teorii postkolonialnej, która tak chętnie go dekonstruuje i rozlicza (zob. Chibber 2013: 1-27).

W rezultacie rozmaitych nakładek znaczeniowych postkolonialnymi podmiotami można nazwać zarówno byłych kolonizatorów, byłych kolonizowanych, byłe kolonie w sensie organizacji państwowej, jak i wszelkie konsekwencje systemu kolonialnego na poziomie makro- i mikrospołecznym, a w rezultacie - można mówić o postkolonialnej światowej rzeczywistości społecznej (Borkowska 2007; Shohat 1992: 103). Co więcej, postkolonialny autor to, zależnie od kontekstu użycia tego terminu, zarówno krytyk spuścizny kolonializmu, jak i jej reproducer (Nowicka 2010). W konsekwencji zyskujemy wielostronny ogląd światowych zależności, ale tracimy pojęciową klarowność. Badania wykorzystujące perspektywę postkolonialną często mają patchworkowy charakter, montujący „wszystko z wszystkim” i redukujący historyczną partykularność kolonizacji do uniwersalnego doświadczenia dominacji. Co najważniejsze, teoria postkolonialna w jej współczesnym kształcie staje się coraz mniej „wywrotna” - jej hybrydowość służy autolegitymizacji tego nurtu. Jeden sens postkolonialności odsyła bowiem do drugiego, a ten 
do następnego - skrywając przezroczystość pojęcia i jego redukcję do pustego signifiant.

\section{Mechaniczne przeniesienie?}

Wątpliwości te nabierają nowego wydźwięku we wschodnioeuropejskim wariancie postkolonializmu, w świetle którego Europa Wschodnia, podobnie jak kolonialny Orient, została „wynaleziona” w XVIII wieku przez zachodnich kupców i podróżników, a jej stygmatyzujący obraz jako zaścianka kontynentu i „podkultury" przetrwał do czasów obecnych (Wolff 1994). Ponadto kulturowe wymiary dominacji sowieckiej na tym obszarze są przyrównywane do kolonialnego uzależnienia à rebours, do „misji antycywilizacyjnej” barbarzyńskiego kolonizatora wobec „bardziej zachodnich” narodów Europy (Zarycki 2013).

Włączenie Europy Wschodniej w obszar zainteresowania teorii postkolonialnej stwarza szansę na to, by w światowych relacjach dominacji dostrzec bardziej złożoną siatkę zależności niż dychotomia „cywilizowany” Zachód i „barbarzyński” Wschód (Tlostanova 2012). Niemniej wydaje się, że relacja postkolonialności do postsocjalizmu i postkomunizmu stanowi przedmiot arbitralnych rozstrzygnięć. Kilkanaście lat temu David Chioni Moore (2001) w eseju zatytułowanym Is the Post- in Postcolonial the Post- in Post-Soviet? zrównał kulturowe wymiary dominacji Związku Sowieckiego nad satelickimi państwami z imperializmem zachodnim, a homo sovieticus z człowiekiem skolonizowanym. Za nim poszli kolejni badacze, widząc w tak zwanym Drugim Świecie - podporządkowanym imperiom Habsburgów, Hohenzollernów i Romanowów, a potem Związkowi Sowieckiemu - prefigurację zamorskiej „trzecioświatowej” kolonizacji. Budowanie mostów między tymi dwiema historiami uzależnienia od imperiów wymaga jednak problematyzacji ideologicznego i politycznego bagażu proponowanej analogii, którą należy prawdopodobnie osłabić na rzecz bardziej zniuansowanej refleksji nad spleceniem czy też krzyżowaniem się tych swoistych historii (Mark, Slobodian 2018). Klasyczny postkolonializm wiąże się z (post)marksistowską krytyką wyzysku kapitalistycznego, w którym upatruje się źródeł podporządkowania Wschodu Zachodowi. Postkomunizm oznacza natomiast stan po obaleniu dyktatury opartej na ideologii antykapitalistycznej. Krytyka postkomunizmu za pomocą narzędzi krytyki postkolonialnej wydaje się zasadna tylko na poziomie metakategorii władzy i dominacji, które wytwarzają podporządkowane sobie podmioty. Jeszcze poważniejsze zastrzeżenia budzi stawianie znaku równości między postkolonializmem a postsocjalizmem. Istotę kondycji postkolonialnej stanowi zmaganie się z przechwyconą przez kolonizatora tożsamością kulturową. Socjalizm prowadził do patologii struktur gospodarczych i politycznych, ale nie był bezpośrednio - inaczej niż stalinizm czy maoizm - wymierzony w tożsamość kulturową społeczeństwa. 
Wschodnioeuropejski, w tym polski, wariant postkolonializmu - diagnozujący w lokalnej przestrzeni kulturowej dyskurs, praktyki i artefakty oparte na hybrydowej zachodnio-wschodniej tożsamości, która miała się formować w warunkach uzależnienia Polski, Węgier, Czech, Słowacji czy Bałkanów od sąsiadujących mocarstw (zwłaszcza Rosji i Związku Sowieckiego) - rzadko problematyzuje kwestię odpowiedniości optyki oraz instrumentarium pojęciowego teorii postkolonialnej do analiz postkomunizmu i postsocjalizmu. Nad terminologiczne i epistemologiczne niejasności przedkładane są komunikacyjne i prestiżowe zyski, które mają płynąć z wpisania doświadczenia Europy Wschodniej w globalną narrację o władzy (por. m.in. Skórczewski 2013; Bátorová 2014). Wysuwane są jednak postulaty, aby wypracować względnie autonomiczną lokalną metodę i wrażliwość studiów postkolonialnych, która umożliwiałaby dialog ze światową (czytaj: anglosaską) akademią, a nie odtwórcze podporządkowanie dominującym w niej tendencjom. Jak ujmuje te zalecenia Jan Kieniewicz (2016: 70): „Postkolonializm jako metoda, podejście czy dyskurs ma w Polsce perspektywy pod warunkiem, że nie będzie ona postkolonialna. (...) Rozszerzanie polskich postcolonial studies o tematykę polską jest i będzie celowe przede wszystkim wtedy, gdy wzorom pozyskanym z mainstreamu potrafimy nadać własną postać".

Trudno przy tym odmówić wschodnioeuropejskiemu wariantowi postkolonializmu wielowymiarowego spojrzenia na regionalne zależności typu kolonialnego - co widać wyraźnie na przykładzie polskiej refleksji. Jeszcze Ewa Thompson, która dzięki Trubadurom imperium (2000) stała się prekursorką polskiej krytyki postkolonialnej, widzi lokalną postkolonialność w sposób jednowektorowy - to Polacy są ofiarami kolonizacji ze strony obcych państw, ponadnarodowych instytucji lub pewnych opcji politycznych (neoliberalizmu). Jednak niedługo po Thompson kolejni badacze upomnieli się o inne, niejednoznaczne role, w które wchodziło społeczeństwo polskie, a zwłaszcza jego elity: „Kto jest kolonizatorem? Rosja wobec Polski? Czy na przykład Polska wobec Ukrainy?” - pyta Grażyna Borkowska (2007: 15). Liberalno-lewicowa lektura teorii postkolonialnej w polskim kontekście wysunęła postulat rozliczenia polskich mitów, między innymi Rzeczpospolitej Obojga Narodów i Kresów Wschodnich, zbudowanych na fantazmatach cywilizowanej Korony i dzikich wschodnich rubieży (zob. m.in. Beauvois 2005; Sowa 2011; Traba 2012).

Na postawie dorobku polskiej krytyki postkolonialnej można, w przeglądowy i siłą rzeczy skrótowy sposób, wyróżnić kilka jej rysów, które spaja kategoria polskiego orientalizmu (inspirowana koncepcją Edwarda W. Saida [2005], tu w rozumieniu Marii Janion [2006]), czyli dyskursu hybrydowej tożsamości osadzonej pomiędzy kulturowym Wschodem a Zachodem. Ów dyskurs wiąże się z taką formą polskiej pamięci zbiorowej, która jest kreowana przez mesjanizację oraz angelizację własnego narodu przy równoczesnej satanizacji jego wrogów (np. Rosji i Związku Sowieckiego). Polski orientalizm podtrzymuje pragnienie ustanowienia unikatowej w oczach Europy tożsamości. To pragnienie ujawnia się w orientali- 
zacji krajów na Wschód od Polski, w narzucaniu tożsamości „bardziej wschodniego Wschodu" niż Polska, która wciąż ma kompleks bycia Wschodem Europy. Współczesne zabiegi odgraniczenia Polski od świata postsowieckiego polegają na przypisywaniu „bardziej wschodniemu Wschodowi” fatalistycznej podatności na poddaństwo polityczne i mentalne oraz na poszukiwaniu „nieskażonej” kolonialnymi zależnościami (zarówno od Wschodu, jak i Zachodu) tożsamości: dumnej, homogenicznej i - używając retoryki obecnych elit władzy, stosujących zresztą niekiedy w instrumentalny sposób słownik krytyki postkolonialnej (zob. Nowicka-Franczak 2017) - powstałej z kolan. Jak twierdzi Stanley Bill (2014: 114):

[n]ie ma nic ironicznego czy niespójnego w projekcie postkolonializmu pisanym przez polskich konserwatystów. Ostatecznie całkiem wprost przedstawia on roszczenie „wskrzeszenia głównych filarów ideologii konserwatywnej”. Polscy konserwatyści przejawiają silny interes w promowaniu kulturowego esencjalizmu i antyuniwersalizmu, chcą bowiem propagować szczególną wizję ekskluzywnej i integralnej „polskości”.

Obszar postkolonialnych relacji Ja - Inny - Obcy wyznaczony jest przez wiele osi, których wspólną cechą jest petryfikowanie hierarchicznych i wartościujących układów zależności. Można wskazać na postkolonialne:

1. konstruowanie różnic narodowościowych i etnicznych: na przykład Polacy - Ukraińcy, Polacy - Wietnamczycy (traktowani jako tania siła robocza) - tu ujawnia się mechanizm źle pojętej „sprawiedliwości dziejowej” opierający się na logice, że skoro Polacy byli i są tanią siłą roboczą w Niemczech czy Wielkiej Brytanii, to pozycję ekonomiczną Polski też buduje obecność gastarbeiterów), Polacy - Rosjanie (w tym przypadku działa mechanizm mesjanizacji i satanizacji), ale także Anglicy, Niemcy czy Amerykanie (jako zarazem przedmiot satyry i krytyki oraz wzór do naśladowania i cywilizacyjnego doganiania). Ukraińcy są natomiast jednocześnie traktowani jako ofiary polskich imperialnych ambicji z przeszłości oraz spadkobiercy antypolskiego nastawienia „bardziej wschodniego Wschodu” (zob. Bielska, Wróblewski 2017);

2. konstruowanie różnic zewnątrzkulturowych (w tym rasowych oraz religijnych): biali - niebiali, katolicy - niekatolicy (żydzi), chrześcijanie muzułmanie, a także heteroseksualna większość - mniejszości seksualne. Przedmiotem stereotypizacji stają się wszyscy ci, którzy są postrzegani jako neokolonizatorzy głównego nurtu kultury, jako wyobrażone zagrożenie dla tak zwanej tradycyjnej tożsamości i wartości kulturowych. Do jesieni 2015 roku artykułowanie tych podziałów było częściowo tłumione przez dyskurs poprawności politycznej, ale kryzys migracyjny w Europie zinterpretowany przez dochodzącą wówczas do władzy w Polsce prawicę doprowadził do wzmożenia i radykalizacji w konstruowaniu tych różnic, podatnych na eskalację w działaniu zbiorowym, jak chociażby w czasie obchodów Święta Niepodległości czy podczas antyislamskich i antyuchodźczych demonstracji. W ostatnich latach w kontekście polityki historycznej rządu Prawa 
i Sprawiedliwości ożywa także antysemicka konstrukcja Żyda jako wroga chcącego wpływać na polską politykę, a więc jako niejawnego kolonizatora lub ukrytego hegemona;

3. konstruowanie różnic wewnątrzkulturowych (światopoglądowych): elektorat PO - elektorat PiS, zwolennicy Unii Europejskiej - jej przeciwnicy. W tym kontekście można mówić o wewnętrznej orientalizacji społecznej następującej w potransformacyjnej gospodarce kapitalistycznej oraz w reakcji na neoliberalną wizję człowieka jako autonomicznej jednostki społeczeństwa. Ten wariant orientalizacji „dzieli społeczeństwo na zwycięzców i przegranych, a ostatecznie na rozsądnych i zdolnych do adaptacji oraz półgłówków, nieudolnych i niezdolnych do tego, by się dostosować" (Buchowski 2008: 101). Od kilku lat zarówno w dyskursie konserwatywnym, jak i lewicowym coraz wyraźniej obecna jest odwrotna wewnętrzna orientalizacja społeczna, w świetle której rozliczeniu powinna podlegać pogarda neoliberalnych elit wobec moralnie wygranej i domagającej się godności klasy ludowej;

4. konstruowanie wielokulturowości: usymbolicznienie (tokenization) i gettoizacja przedstawicieli tak zwanego Trzeciego Świata. W przybyszach z zewnątrz widzi się symboliczną kwintesencję inności, aby stworzyć sobie iluzję własnej otwartości na Innego, tolerancji i wielokulturowego przepływu (Spivak 2011) lub symbolicznie eksternalizować na Innego przyczyny poczucia, że zagrożone jest kulturowe status quo.

Wymienione konstrukty społeczne są reprodukowane i utrwalane w kulturze symbolicznej i dyskursie publicznym. Mogą stanowić endemityczne rezerwuary świadomości kolonialnej lub skolonizowanej (Bakuła 2006). Należy jednak zadać pytanie, czy do diagnozowania wskazanych podziałów i krytycznego namysłu nad nimi konieczne są kategorie postkolonialne. Czy socjologiczna i antropologiczna refleksja nad społeczeństwem postkomunistycznym lub postsocjalistycznym nie prowadzi do zbliżonych wniosków o żywotności zbiorowych kompleksów, antysemityzmu, rusofobii i paternalizmu wobec słabszych? Czy postkolonialna rama nie służy raczej jako nośna metafora mająca pozwolić zaistnieć wschodnioeuropejskiej perspektywie na międzynarodowym rynku idei?

Odwołanie do postkolonializmu pozwala uciec zarówno od niewygodnych ram postkomunizmu i postsocjalizmu, eksploatowanych w dyskursie polityki, jak i od lokalności ich krytyki. Jaka jest jednak wartość teorii, która zajmuje się nierównościami kolonialnego typu na całym świecie i w różnych kontekstach? Czy teoria do wszystkiego nie staje się teorią do niczego? Kategorie krytyki postkolonialnej nie uwzględniają stricte polskiego kontekstu historycznego. Polska nigdy nie była kolonią ani metropolią w prawno-politycznym sensie tego słowa, ale obszarem politycznie zdominowanym przez władzę niemającą szerokiej legitymacji społecznej. Dlatego zresztą Hanna Gosk (2008: 75) proponuje mówić o Polsce postzaborowej (w okresie międzywojennym) i postzależnościowej (po 
1989 roku), a nie postkolonialnej¹. Ponadto źródłem nierówności społecznych są różnice w dostępie nie tylko do kapitału ekonomicznego, ale także do kapitału kulturowego, który wciąż odgrywa ważną rolę w selekcji elit (Zarycki 2009). Wschodnioeuropejski wariant teorii postkolonialnej być może jest tylko w stanie unaocznić napięcia między ideami Europy i nie-w-pełni Europy (zob. Grzymski 2016: 50), gdyż sam jest efektem transferu idei z Zachodu na jego peryferia.

\section{Fetysz modernizacji}

Polska refleksja, mierząc się z problemem kolonialnego dziedzictwa, reinterpretuje go na dwa podstawowe sposoby, które polemizują - każdy na swój sposób - z dyskursem imitacyjnej prozachodniej modernizacji Europy Wschodniej. Z jednej strony symptomy „postkolonialnej kondycji” Polski dostrzega się w niemożności zerwania z postkomunistyczną stagnacją, w czerpaniu kulturowych wzorów z Europy Zachodniej, w konieczności podporządkowania się dyrektywom UE czy w ekspansji dyskursów neoliberalnych. Odpowiedzią na te procesy ma być „powrót do źródeł”, którymi, zależnie od politycznych inklinacji badaczy, są ideały sarmacko-szlacheckiej witalności bądź chłopsko-proletariackie rudymenty kultury. Warto zatrzymać się chwilę nad tą pierwszą wizją, obecną zwłaszcza w pracach (i w tekstach publicystycznych) Ewy Thompson (2000, 2005, 2006). Ta propozycja ma, na pierwszy rzut oka, charakter antymodernizacyjny. W jej świetle alternatywą jest albo westernizacja i związana $\mathrm{z}$ nią utrata polskiej tożsamości, albo, zalecany przez Thompson, powrót do dumy narodowej i wartości sarmackich. Można jednak w tym apelu o powrót polskiej kultury „przedkolonialnej” dostrzec potencjał alternatywnej modernizacji, konkurencyjnej wobec „doganiania” Zachodu w sferze aksjologicznej. Jeżeli jednak spojrzymy na materialne warunki, w których miałby się dokonywać ów społeczny „powrót do źródeł” - jest to wizja liberalnej, kapitalistycznej gospodarki i republikańskich rządów, a więc oparta na ideach zaczerpniętych $\mathrm{z}$ konserwatywnej myśli Zachodu².

$\mathrm{Z}$ drugiej strony postkolonialną kondycję Polski łączy się $\mathrm{z}$ mentalnym ciążeniem ku wyobrażonemu Wschodowi i brakiem rozliczenia własnych prób kolonizacji Ukrainy czy Litwy. Tak rozumiana postkolonialność staje się przeszkodą na drodze do kulturowego modernizmu w polskim społeczeństwie. Przezwyciężenie postkolonialności zostaje powiązane nie tyle z twórczą autopracą społeczeństwa, ile z jego dostosowaniem do zachodnich standardów demokracji.

1 Znamienne, że ta propozycja nie zyskała szerokiej akceptacji. Być może dlatego, że kwestionuje cechujące współczesną teorię postkolonialną roszczenie do uniwersalnego wymiaru kategorii postkolonialności.

2 Taka interpretacja postkolonializmu w polskich warunkach ignoruje marksistowską i postmarkskistowską genezę teorii postkolonialnej, „niewygodną” do rozliczania komunizmu i socjalizmu (zob. Sowa 2011). 
Można widzieć w tym „wyraz ideologii modernizacji imitacyjnej, przyjmowanej głównie w dyskursie publicznym i widocznej w programowaniu strategii rozwojowych, ale obecnej też w analizach o charakterze naukowym" (Kolasa-Nowak 2013: 106; zob. także m.in. Koczanowicz 2011; Sowa 2011). Projektowany człowiek zdekolonizowany ma też bardzo zbliżone rysy do kapitalistycznego, neoliberalnego homo oeconomicus, który zarządza swoją wolnością w sposób przynoszący wymierne zyski na mikro- i na makrospołecznym poziomie (Bröckling 2007).

Te dwa wykluczające się ujęcia polskiej postkolonialności egzystują obok siebie, wyjaskrawiając elitarny charakter omawianej tu oferty teoretycznej. Postsowiecka mentalność i opór wobec modernizacji, jakkolwiek rozumianej, dotyczy bowiem zawsze kogoś innego, słabszego, uboższego niż ten, kto apeluje o ich odrzucenie (zob. Rakowski 2009). Asymetryczność tej relacji sprawia, że na apel skierowany do wszystkich mogą odpowiedzieć tylko nieliczni. Pozostali - „niepodmiotowa” masa - stają się przedmiotem zabiegów, które, toutes proportions gardées, można nazwać formą orientalizacji, czyli narzucania dalekiemu, ale także bliskiemu Innemu pośledniej tożsamości człowieka Wschodu (zob. Nowicka-Franczak 2017).

Co więcej, „perforowany” charakter dyskursu teorii postkolonialnej, w tym jej wschodnioeuropejskiej odmiany, stymuluje przepływy między dyskursem nauki a dyskursem politycznym. W konsekwencji kategorie i postulaty badawcze nierzadko zostają zredukowane do wymiaru retorycznego i stają się elementem instrumentalnych strategii promowania określonych opcji światopoglądowych. Jest to obserwowalne nie tylko w polskiej debacie publicznej, gdzie ekspiacyjno-rozliczeniowy dyskurs ściera się z tradycjonalistyczno-narodowym, ale także w komunikacji skierowanej do Innego. O ile zachodnioeuropejska opinia publiczna wydaje się niepodatna na udramatyzowany paternalizm Europy Wschodniej, o tyle wspomniany wyżej „bardziej wschodni Wschód” staje się, chcąc nie chcąc, bezpośrednim adresatem tego dyskursu. Mimo różnic w zakresie doświadczeń historycznych Polska jest przedstawiana jako wzór do naśladowania i przykład prozachodniego modelu transformacji dla Ukrainy i Białorusi. Tym samym dziedzictwo trudnych relacji między państwami regionu (związane z polonizacją Kresów i buntem przeciw niej) jest wtórnie mitologizowane (Bekus 2013) - jako odwieczna opowieść o zrywaniu kajdan i misji cywilizacyjnej wobec słabszych.

Wschodnioeuropejski wariant teorii postkolonialnej nie może być prostą narracją o ujarzmieniu i zrzuceniu tego jarzma. Powinien natomiast analitycznie rekonstruować i kontekstualizować wielopoziomowe uzależnienie krajów i społeczeństw tego regionu od Centrum - które raz znajdowało się na geograficznym Zachodzie, innym razem na Wschodzie, czasem na Południu, rzadziej na Północy. Dlatego pomocne i zasadne wydaje się wzmocnienie krytyki stricte postkolonialnej Wallersteinowską oraz Bourdiańską refleksją nad dynamicznymi relacjami centro-peryferyjnymi i cyrkulacją różnego typu kapitałów. Aby uniknąć poznawczej wtórności, a może wręcz jałowości, wschodnioeuropejski peryferyjny postkolonializm nie powinien być kolejną teorią o pełzającej modernizacji, która 
napotyka przeszkody i niekiedy prowadzona jest przemocowo, ale ostatecznie upodabnia Wschód do Zachodu. Dobrze by było, gdyby zamiast tego teoria ta uwzględniała lokalne odmiany modernizacji oraz towarzyszące jej imaginaria, rywalizujące i mieszające się z zasobami westernizacji. W przeciwnym wypadku może stać się swoistym konglomeratem resentymentów i poręcznym narzędziem zarówno mobilizacji do „wstawania z kolan”, jak i apelowania o „więcej Zachodu na Wschodzie”. Ucieczka refleksji krytycznej nad Europą Wschodnią w postkolonializm jako teorię oraz w postkolonialność jako język mówienia o własnym doświadczeniu staje się ucieczką przed zmarginalizowaniem i światowym milczeniem prowincjonalnych teorii. Wpisanie się $\mathrm{w}$ głos postkolonializmu, który należy do głównego nurtu teorii społecznej, pozwala odbić się w cudzym lustrze, ale nie może zwalniać z krytycznego oglądu zapożyczeń. Jeżeli zapomnimy o tym „oglądaniu się za siebie”, krytyka pożre samą siebie, wpisując się wtórnie w dyskursy, które miała kwestionować.

\section{Bibliografia}

Ascione G.

2016 Decolonizing the "Global": The Coloniality of Method and the Problem of the Unit of Analysis, „Cultural Sociology”, t. 10(3), s. 317-334.

Bakuła B.

2006 Kolonialne i postkolonialne aspekty polskiego dyskursu kresoznawczego (zarys problematyki), „Teksty Drugie”, nr 6, s. 11-33.

Bátorová M.

2014 Slovak Literature and Culture from the „Postcolonial” Perspective, „Primerjalna Književnost", t. 37(3), s. 73-88.

Beauvois D.

2005 Trójkąt ukraiński. Szlachta, carat i lud na Wołyniu, Podolu i Kijowszczyźnie 17931914, przeł. K. Rutkowski, Lublin.

Bekus N.

2013 Kresy wschodnie w obliczu białoruskości. Obraz Polski w białoruskim dyskursie kulturowym, w: T. Zarycki (red.), Polska Wschodnia i orientalizm, Warszawa, s. 67-89.

Bielska B., Wróblewski M.

2017 Central-Eastern Europe as Postcolonially Involved (Sub)peripheries, „Eastern European Coutryside", nr 23, s. 209-220.

Bill S.

2014 W poszukiwaniu autentyczności. Kultura polska i natura teorii postkolonialnej, „Praktyka Teoretyczna”, nr 11, s. 107-127.

Borkowska G.

2007 Polskie doświadczenie kolonialne, „Teksty Drugie”, nr 4, s. 15-24.

Bröckling U.

2007 Das unternehmerische Selbst. Soziologie einer Subjektivierungsform, Frankfurt am Main. 
Buchowski M.

2008 Widmo orientalizmu w Europie. Od egzotycznego Innego do napiętnowania swojego, „Recykling Idei”, nr 10, s. 98-107.

Chibber V.

2013 Postcolonial Theory and the Specter of Capital, London-New York.

Domańska E.

2008 Obrazy PRL-u w perspektywie postkolonialnej, w: K. Brzechczyn (red.), Obrazy PRL-u, Poznań, s. 167-186.

2016 Problem sprawiedliwości epistemicznej i dekolonizacja postkolonializmu (Casus Europy Środkowo-Wschodniej), w: J. Kieniewicz (red.), Debaty Artes Liberales Tom X. Perspektywy postkolonializmu w Polsce, Polska w perspektywie postkolonialnej, Warszawa, s. 39-53.

Gandhi L.

2008 Teoria postkolonialna, przeł. J. Serwański, Poznań.

Gosk H.

2008 Polskie opowieści w dyskurs postkolonialny ujęte, w: H. Gosk, B. Karwowska (red.), (Nie)obecność. Pominięcia i przemilczenia w narracjach XX wieku, Warszawa, s. $74-88$.

Grzymski J.

2016 Powrót do Europy - polski dyskurs. Wyznaczanie perspektywy krytycznej, Warszawa.

Hall S.

1996 When was „the Post-Colonial”? Thinking at the Limit, w: I. Chambers, L. Curti (eds.), The Post-Colonial Question, London-New York, s. 242-260.

Janion M.

2006 Niesamowita słowiańszczyzna, Kraków.

Kieniewicz J.

2016 O perspektywę dla Polski, w: J. Kieniewicz (red.), Debaty Artes Liberales Tom X. Perspektywy postkolonializmu $w$ Polsce, Polska w perspektywie postkolonialnej, Warszawa, s. 69-86.

Koczanowicz L.

2011 My skolonizowani? Wschodnioeuropejskie doświadczenie i teoria postkolonialna, „Nowa Krytyka”, nr 26-27, s. 181-194.

Kolasa-Nowak A.

2013 Użyteczność obrazu Polski wschodniej w dyskursie akademickim i publicznym, w: T. Zarycki (red.), Polska Wschodnia i orientalizm, Warszawa, s. 98-109.

Kołodziejczyk D.

2010 Postkolonialny transfer na Europę Środkowo-Wschodnią, „Teksty Drugie”, nr 5, s. $22-39$.

Loomba A.

2011 Kolonializm/postkolonializm, przeł. N. Bloch, Poznań.

Mark J., Slobodian Q.

2018 Eastern Europe, w: M. Thomas, A. Thompson (eds.), The Oxford Handbook of the Ends of Empire, Oxford.

McClintock A.

1992 The Myth of Progress: Pitfalls of the Term Post-colonialism, „Social Text”, nr 31-32, s. 84-98. 
Moore D.Ch.

2001 Is the Post- in Postcolonial the Post- in Post-Soviet? Towards a Global Postcolonial Critique, „PLMA”, nr 1 (116), s. 111-128.

Nowicka M.

2010 Czy teoria postkolonialna jest kobieca? Narodziny, rozwój i zmierzch postkoloniali$z m u$, „Przegląd Socjologiczny”, nr 3 (LIX), s. 109-130.

Nowicka-Franczak M.

2017 Perspektywa postkolonialna a społeczno-krytyczna wrażliwość badacza polskiego dyskursu publicznego, w: M. Czyżewski, M. Otrocki, T. Piekot, J. Stachowiak (red.), Analiza dyskursu publicznego. Przeglad podejść i metod, Warszawa, s. 253-270.

Rakowski T.

2009 Łowcy, zbieracze, praktycy niemocy. Etnografia człowieka zdegradowanego, Gdańsk. Said E.W.

2005 Orientalizm, przeł. M. Wyrwas-Wiśniewska, Poznań.

Shohat E.

1992 Notes on the „Post-Colonial”, „Social Text”, nr 31-32, s. 99-113.

Skórczewski D.

2013 Teoria - literatura - dyskurs. Pejzaż postkolonialny, Lublin.

Sowa J.

2011 Fantomowe ciało króla. Peryferyjne zmagania z nowoczesna forma, Kraków.

Spivak G.Ch.

2011 Strategie postkolonialne, przeł. A. Górny, Warszawa.

Thompson E.

2000 Trubadurzy imperium. Literatura rosyjska i kolonializm, przeł. A. Sierszyńska, Kraków.

2005 Said a sprawa polska. Przeciwko kulturowej bezsilności peryferii, „Europa. Tygodnik Idei", nr 65, s. 11.

2006 Sarmatyzm i postkolonializm. O naturze polskich resentymentów, „Europa. Tygodnik Idei", nr 46, s. 11.

Tlostanova M.

2012 Postsocialist $\neq$ postcolonial? On post-Soviet Imaginary and Global Coloniality, „Journal of Postcolonial Writing”, nr 2 (48), s. 130-142.

Todorova M.

2008 Bałkany wyobrażone, przeł. P. Szymor, M. Budzińska, Wołowiec.

Traba R.

2012 Kresy jako miejsce pamięci - historia długiego trwania, „Herito”, nr 8, s. 58-91.

Wolff L.

1994 Inventing Eastern Europe. The Map of Civilisation on the Mind of Enlightenment, Stanford.

Zarycki T.

2009 Socjologia krytyczna na peryferiach, „Kultura i Społeczeństwo”, nr 1, s. 105-121.

2013 Debating Soviet Imperialism in Contemporary Poland: On the Polish uses of Post-

Colonial Theory and Their Contexts, w: S. Turoma. M.K. Waldstein (eds.), Empire De/

Centered: New Spatial Histories of Russia and the Soviet Union, Ashgate, s. 191-215.

2014 Ideologies of Eastness in Central and Eastern Europe, London-New York. 